(c) American Dairy Science Association, 2003.

\title{
Prepartum Antibiotic Treatment of Heifers: Milk Production, Milk Quality and Economic Benefit
}

\author{
S. P. Oliver, ${ }^{*}$ M. J. Lewis, ${ }^{\star}$ B. E. Gillespie, ${ }^{*}$ H. H. Dowlen, ${ }^{*}$ E. C. Jaenicke†, ${ }^{1}$ and R. K. Roberts $†$ \\ ${ }^{*}$ Department of Animal Science and †Department of Agricultural Economics, \\ Institute of Agriculture, \\ The University of Tennessee, \\ Knoxville 37996
}

\begin{abstract}
Prepartum intramammary antibiotic infusion of heifer mammary glands at 7 or $14 \mathrm{~d}$ before expected parturition is an effective procedure for eliminating many infections in heifers during late gestation and for reducing the prevalence of mastitis in heifers during early lactation and throughout lactation. Mastitis pathogens were isolated from $76 \%$ of samples obtained from untreated control quarters $7 \mathrm{~d}$ before expected calving, from $47 \%$ of samples obtained $3 \mathrm{~d}$ after calving, and from $29 \%$ of samples obtained $10 \mathrm{~d}$ postpartum. Mastitis pathogens were isolated from about $30 \%$ of control quarters through $240 \mathrm{~d}$ of lactation. A similar percentage of samples (70\%) was positive for mastitis pathogens at C-7 before antibiotic treatment. However, only $8 \%$ of samples obtained at $3 \mathrm{~d}$ after calving and $4 \%$ of samples obtained at $10 \mathrm{~d}$ postpartum from quarters of antibiotic-treated heifers contained mastitis pathogens. Throughout the remainder of lactation, mastitis pathogens were isolated from an average of about $11 \%$ of quarters. The percentage of samples with mastitis pathogens was higher in untreated controls than in antibiotic-treated quarters at all sampling intervals during lactation. A similar response was observed in heifers that were treated with antibiotics at $14 \mathrm{~d}$ before expected parturition. Prepartum antibiotic-treated heifers produced significantly more milk than control heifers and had significantly lower somatic cell count scores than untreated control heifers. These observations are likely associated with or due to the lower prevalence of mastitis pathogen isolation in prepartum antibiotic-treated heifers throughout lactation. Prepartum antibiotic-treated heifers produced $531 \mathrm{~kg}$ more milk than heifers in the untreated control group. Multiplying this increase by a milk price of $\$ 0.407 / \mathrm{kg}$ yielded
\end{abstract}

Received August 32001.

Accepted October 23, 2001.

Corresponding author: S. P. Oliver; e-mail: soliver@utk.edu.

${ }^{1}$ Current address: Department of Agricultural Economics and Rural Sociology, Penn State University, University Park, PA 16802. a $\$ 216.24$ per-heifer increase in gross revenue. The cost of treatment, including the cost of testing for antibiotic residues, was estimated at $\$ 15.60$ for a net revenue of $\$ 200.64$ per heifer. Prepartum antibiotic treatment to reduce the rate of mastitis in heifers during lactation was highly effective and economically beneficial.

(Key words: heifer, mastitis, intramammary infection, economics)

\section{INTRODUCTION}

Mammary glands of unbred and pregnant heifers were once thought to be uninfected. However, Oliver and Mitchell (1983) showed that a high percentage of pregnant heifer mammary glands were infected during late gestation, at calving and during early lactation. During the last decade, several additional studies on the prevalence of mastitis in heifers have been published (Oliver, 1987; 1988; Oliver and Sordillo, 1988; Trinidad et al., 1990a; Pankey et al., 1991; Matthews et al., 1992; Smith et al., 1994; Fox et al., 1995; Nickerson et al., 1995). All of these studies suggest that IMI in heifers during the prepartum period occur frequently. One common denominator of all studies reported thus far was that coagulase-negative Staphylococcus species caused the majority of IMI in unbred and pregnant heifers. However, variation in the prevalence of other mastitis pathogens should be expected among herds.

In our studies (Oliver, 1987; Oliver et al., 1992; Oliver et al., 1997), 8 to $10 \%$ of heifer mammary glands were infected with major mastitis pathogens near calving. Most major pathogen IMI were caused by environmental mastitis pathogens, primarily Streptococcus uberis and Streptococcus dysgalactiae, which was consistent with the pattern of IMI in lactating cows in these herds. Conversely, other studies (Fox et al., 1995; Trinidad et al., 1990a) indicated that Staphylococcus aureus was the most prevalent major mastitis pathogen isolated from unbred and pregnant heifer mammary glands.

Mammary secretions from infected mammary glands had significantly higher SCC than secretions from unin- 
fected mammary glands (Trinidad et al., 1990b; Hallberg et al., 1995). In addition, tissue from mammary glands of unbred heifers infected with coagulase-negative Staphylococcus species exhibited greater leukocyte infiltration and increased connective tissue compared with tissue from uninfected mammary glands (Trinidad et al., 1990b). Thus, infection of heifer mammary glands by mastitis pathogens can occur at a very early age and some of these infections may impair mammary growth and development and influence future milk production.

Previous studies (Oliver et al., 1992; Oliver et al., 1997) showed that significantly fewer antibiotic-treated heifer mammary glands were infected during early lactation following prepartum antibiotic treatment than in untreated control heifers. However, in both of those studies, the influence of prepartum antibiotic treatment on the infection status of heifer mammary glands or prevalence of mastitis pathogen isolation was confined to early lactation. The purpose of the present study was to determine whether prepartum antibiotic therapy of heifer mammary glands influenced prevalence of mastitis pathogen isolation throughout lactation and to quantify the economic consequences associated with prepartum antibiotic treatment of heifers over an entire lactation.

\section{MATERIALS AND METHODS}

This study was a continuation of two previous studies that evaluated efficacy of prepartum intramammary antibiotic therapy on mastitis in heifers during early lactation. In study one (Oliver et al., 1992), primigravid Jersey heifers $(n=115)$ from the University of Tennessee Dairy Experiment Station research herd at Lewisburg were assigned alternately to three treatment groups: 1) no intramammary antibiotic infusion ( $\mathrm{n}=$ 41 ), 2) intramammary infusion of all quarters with 200 $\mathrm{mg}$ of sodium cloxacillin (Beecham Laboratories, Bristol, TN) $7 \mathrm{~d}$ before expected parturition $(\mathrm{n}=38)$, and 3) intramammary infusion of all quarters with $200 \mathrm{mg}$ of cephapirin sodium (Bristol Myers, Evansville, IN) 7 $\mathrm{d}$ before expected parturition $(\mathrm{n}=36)$.

In study 2, primigravid Jersey heifers from the University of Tennessee Dairy Experiment Station research herd were assigned randomly to two treatment groups as follows: group $1(\mathrm{n}=42)$, no intramammary antibiotic infusion (untreated negative control); group $2(n=40)$, intramammary infusion of all mammary glands with $200 \mathrm{mg}$ of cephapirin sodium (Bristol Myers, Evansville, IN) $14 \mathrm{~d}$ before expected parturition.

In the present study, data from microbiological evaluation of milk samples collected from heifers at intervals throughout lactation were evaluated. Quarter samples of mammary secretion were collected for microbiological evaluation from heifers in study one $7 \mathrm{~d}$ before expected calving (C-7), at $3,10,11$ to 30,31 to 90,91 to 150 , 151 to 240 , and $>241$ DIM, and at the last milking of lactation immediately before drying off.

Quarter samples of mammary secretion were collected for microbiological evaluation from heifers in study two at $14 \mathrm{~d}$ before expected calving, at 3, 4 to 30 , 31 to 90,91 to 150,151 to 240 , and >241 DIM, and at the last milking of lactation immediately before drying off.

Microbiological procedures were as described by Oliver et al. (1997). Samples of mammary secretion (10 $\mu \mathrm{l})$ from each mammary gland were plated onto one quadrant of a trypticase soy agar plate supplemented with 5\% defibrinated sheep blood (Becton Dickinson Microbiology Systems, Cockeysville, MD). Plates were incubated at $37^{\circ} \mathrm{C}$, and bacterial growth was observed and recorded at 24-h intervals for $3 \mathrm{~d}$. Bacteria on primary culture medium were identified tentatively according to colony morphologic features, hemoltyic characteristics, Gram stain reaction, and catalase test. Isolates identified presumptively as staphylococci were tested for coagulase production by the tube coagulase method and all coagulase-positive isolates were plated on mannitol agar. Isolates identified presumptively as streptococci were evaluated initially for growth in $6.5 \%$ $\mathrm{NaCl}$, hydrolysis of esculin and sodium hippurate, and CAMP reaction. Streptococcal organisms were identified to the species level using the API 20 Strep system (bioMérieux Vitek, Inc., Hazelwood, MO) and a streptococcal agglutination system (Streptex, Wellcome Diagnostics, Research Triangle Park, NC). Gram-negative isolates were identified to the species level using the following biochemical tests: triple sugar iron, urea, oxidase, motility, indole, and ornithine decarboxylase and by the API $20 \mathrm{E}$ identification system (bioMérieux Vitek, Inc.).

Data were expressed as percentage of samples containing mastitis pathogens. The number of mammary glands from which mastitis pathogens were isolated was expressed as a percentage of the total number of samples examined at each of the above time periods. Differences in the percentage of mammary glands with mastitis pathogens between untreated negative control and antibiotic-treated mammary glands at each sampling period were determined by Student's $t$ test as follows: $t=\left(\mathrm{P}_{1}-\mathrm{P}_{2}\right) /\left[\left(\mathrm{P}_{1} \mathrm{Q}_{1} / \mathrm{N}_{1}\right)+\left(\mathrm{P}_{2} \mathrm{Q}_{2} / \mathrm{N}_{2}\right)\right]^{0.5}$, where the denominator is the standard error of difference between binomially distributed means, $\mathrm{P}_{1}=$ percentage of mastitis pathogen-positive mammary glands in the untreated negative control group, $\mathrm{Q}_{1}=$ percentage of mastitis pathogen-negative mammary glands in the untreated negative control group, $\mathrm{N}_{1}=$ number of mammary glands in the untreated control group, $\mathrm{P}_{2}=$ percentage of mastitis pathogen-positive mammary glands in 
the antibiotic-treated group, $\mathrm{Q}_{2}=$ percentage of mastitis pathogen-negative mammary glands in the antibiotictreated group, and $\mathrm{N}_{2}=$ number of mammary glands in the antibiotic-treated group (Oliver et al., 1992).

\section{Influence of Prepartum Intramammary Antibiotic Treatment of Heifers on Lactational Performance}

The influence of prepartum antibiotic treatment on subsequent lactational performance of heifers was determined. Extrapolated lactation total milk production and 305-d milk production and lactation average SCC data obtained from DHI records from antibiotic-treated and control heifers were evaluated by analysis of variance using the general linear models procedures of SAS (Cary, NC).

\section{Economic Analysis}

Partial budgeting (Boehlje and Eidman, 1984) was used to estimate the net revenue increase for the antibiotic-treated group over the untreated control group. This economic analysis method only accounts for revenues and costs that change from one management practice to another. Actual heifer milk production data from both studies were combined and used in the economic analysis. The price of fluid milk used in the analysis was $\$ 0.4076 / \mathrm{kg}$. The per-heifer net revenue change from treatment was calculated by the following formula: NR $=p\left(Q^{T}-Q^{U}\right)-C^{T}$, where NR is the net revenue change from treatment, $p$ is the price of milk, $Q^{T}-Q^{U}$ is the difference in milk production for treated and untreated groups, and $\mathrm{C}^{\mathrm{T}}$ is the cost of treatment. A wage rate of $\$ 10.00 / \mathrm{h}$ was used in calculating $\mathrm{C}^{\mathrm{T}}$. All other costs were assumed to be the same between groups. Treatment costs of $\$ 15.60$ per heifer were as follows: teat hygiene (\$0.10) which included the cost of a premilking teat disinfectant, barrier postmilking teat disinfectant and disposable paper towels; antibiotics $(\$ 10.00)$; and labor (\$2.50). Another cost that may arise is the cost of testing for antibiotic residues in milk of heifers that calve too soon after treatment. In this analysis, an additional cost of $\$ 3.00$ was assigned to the antibiotictreated group; however, actual costs will likely be less if only those heifers calving early require antibiotic residue testing. We calculated NR and examined how it varied as $p, Q^{T}-Q^{U}$, and the wage rate changed. Breakeven analysis (Boehlje and Eidman, 1984) was performed for $p, Q^{T}-Q^{U}$, and the wage rate by setting the NR equation equal to zero and solving for one of the three variables while holding the other two variables constant at the aforementioned levels. When NR equals zero, net revenue for the treated group equals net revenue for the untreated control, suggesting that treatment provides no economic advantage.

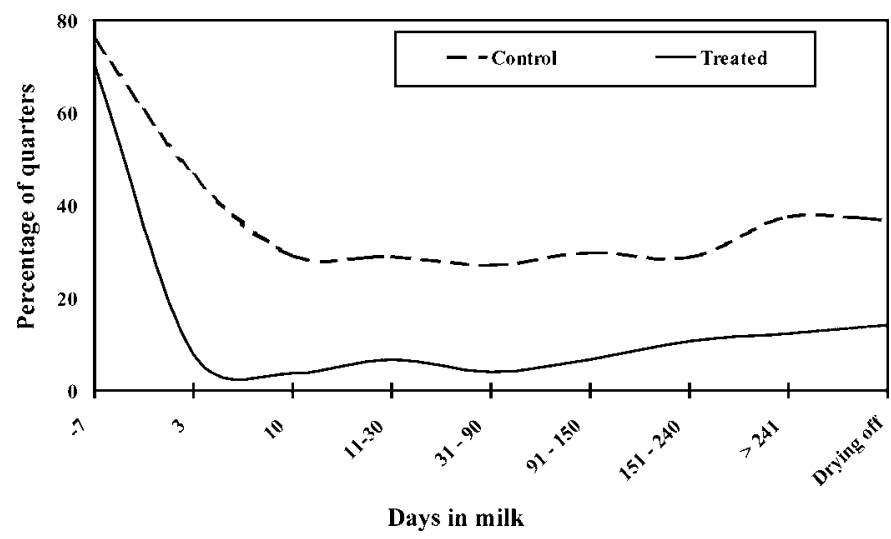

Figure 1. Isolation of mastitis pathogens in milk from control and antibiotic-treated mammary glands throughout lactation following antibiotic treatment of heifers $7 \mathrm{~d}$ before expected parturition.

\section{RESULTS AND DISCUSSION}

\section{Study 1}

Mastitis pathogens were isolated from $76 \%$ of samples obtained from untreated control quarters $7 \mathrm{~d}$ before expected calving, $47 \%$ of samples obtained $3 \mathrm{~d}$ after calving, and $29 \%$ of samples obtained $10 \mathrm{~d}$ postpartum (Figure 1). Mastitis pathogens were isolated from about $30 \%$ of control quarters through $240 \mathrm{~d}$ of lactation. An increase in mastitis pathogen isolation was observed during late lactation ( $>241$ DIM). A similar percentage of samples $(70 \%)$ was positive for mastitis pathogens at C-7 prior to antibiotic treatment. However, only $8 \%$ of samples obtained at $3 \mathrm{~d}$ after calving and $4 \%$ of samples obtained at $10 \mathrm{~d}$ postpartum from quarters of antibiotictreated heifers contained mastitis pathogens. Throughout the remainder of lactation, mastitis pathogens were isolated from an average of about $11 \%$ of quarters. As seen in controls, an increase in mastitis pathogen isolation was observed during late lactation ( $>241 \mathrm{DIM})$. Percentage of samples with mastitis pathogens was higher $(P<0.01)$ in untreated controls than in antibiotic-treated quarters at all sampling intervals during lactation (Figure 1). Coagulase-negative Staphylococcus species, Strep. uberis and Streptococcus dysgalactiae were isolated most frequently in both untreated controls and antibiotic-treated heifer mammary glands (Table 1).

\section{Study 2}

Mastitis pathogens were isolated from $72 \%$ of samples obtained from untreated control quarters $14 \mathrm{~d}$ before expected calving, $63 \%$ of samples obtained $3 \mathrm{~d}$ after calving, and $41 \%$ of samples obtained 4 to $30 \mathrm{~d}$ postpartum (Figure 2). Throughout the remainder of lactation, 
Table 1. Prevalence of mastitis pathogen isolation in milk from control and antibiotic-treated mammary glands throughout lactation following antibiotic treatment $7 \mathrm{~d}$ before expected parturition ${ }^{1}$.

\begin{tabular}{|c|c|c|c|c|c|}
\hline Group ${ }^{2}$ & DIM & $\mathrm{CNS}^{4}$ & Streps $^{5}$ & S. aureus & $\mathrm{GNR}^{6}$ \\
\hline Control & \multirow[t]{2}{*}{$-7^{3}$} & 65.1 & 6.0 & 1.8 & 3.0 \\
\hline Treated & & 62.7 & 4.0 & 1.7 & 2.0 \\
\hline Control & \multirow[t]{2}{*}{3} & 37.2 & 8.7 & 0 & 0.6 \\
\hline Treated & & 5.4 & 0.6 & 0.6 & 1.2 \\
\hline Control & \multirow[t]{2}{*}{10} & 26.4 & 2.1 & 0.7 & 0 \\
\hline Treated & & 2.9 & 0.4 & 0 & 0.4 \\
\hline Control & \multirow[t]{2}{*}{$11-30$} & 25.5 & 2.0 & 1.5 & 0 \\
\hline Treated & & 4.9 & 0.6 & 0.6 & 0.6 \\
\hline Control & \multirow[t]{2}{*}{$31-90$} & 23.6 & 2.4 & 0.5 & 0.5 \\
\hline Treated & & 3.4 & 0.3 & 0 & 0.3 \\
\hline Control & \multirow[t]{2}{*}{$91-150$} & 27.7 & 1.3 & 0.7 & 0 \\
\hline Treated & & 5.8 & 0.6 & 0.3 & 0 \\
\hline Control & \multirow[t]{2}{*}{$151-240$} & 25.5 & 1.4 & 1.9 & 0 \\
\hline Treated & & 7.7 & 2.1 & 0.9 & 0 \\
\hline Control & \multirow[t]{2}{*}{$>241$} & 34.9 & 2.6 & 0 & 0 \\
\hline Treated & & 8.9 & 2.4 & 0.7 & 0.3 \\
\hline Control & \multirow[t]{2}{*}{ Drying off } & 35.3 & 0.8 & 0 & 0.8 \\
\hline Treated & & 10.5 & 2.0 & 0.8 & 0.8 \\
\hline
\end{tabular}

${ }^{1}$ Data expressed as percentage of quarter samples.

${ }^{2} \mathrm{n}=164$ untreated quarters and 296 antibiotic-treated quarters.

${ }^{3}$ Days before expected calving.

${ }^{4}$ Coagulase-negative Staphylococcus species.

${ }^{5}$ Streptococcus species.

${ }^{6}$ Gram-negative rods.

mastitis pathogens were isolated from about $46 \%$ of quarter samples. A similar percentage of samples (72\%) was positive for mastitis pathogens at C-14 before antibiotic treatment. However, only $15 \%$ of samples ob-

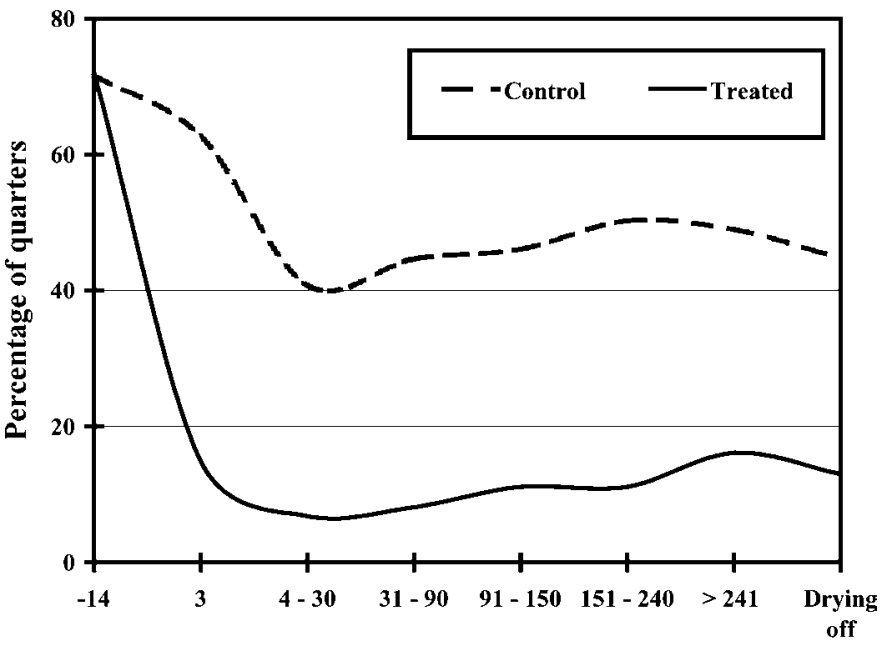

Days in milk

Figure 2. Isolation of mastitis pathogens in milk from control and antibiotic-treated mammary glands throughout lactation following antibiotic treatment of heifers $14 \mathrm{~d}$ before expected parturition.
Table 2. Prevalence of mastitis pathogen isolation in milk from control and antibiotic-treated mammary glands throughout lactation following antibiotic treatment $14 \mathrm{~d}$ before expected parturition ${ }^{1}$.

\begin{tabular}{|c|c|c|c|c|c|}
\hline Group $^{2}$ & DIM & $\mathrm{CNS}^{4}$ & Streps ${ }^{5}$ & S. aureus & $\mathrm{GNR}^{6}$ \\
\hline $\begin{array}{l}\text { Control } \\
\text { Treated }\end{array}$ & $-14^{3}$ & $\begin{array}{l}51.5 \\
56.5\end{array}$ & $\begin{array}{l}3.7 \\
7.1\end{array}$ & $\begin{array}{l}5.2 \\
1.3\end{array}$ & $\begin{array}{l}3.0 \\
1.9\end{array}$ \\
\hline $\begin{array}{l}\text { Control } \\
\text { Treated }\end{array}$ & 3 & $\begin{array}{r}53.4 \\
7.8\end{array}$ & $\begin{array}{l}5.0 \\
0.6\end{array}$ & $\begin{array}{l}1.7 \\
0\end{array}$ & $\begin{array}{l}0.8 \\
1.9\end{array}$ \\
\hline $\begin{array}{l}\text { Control } \\
\text { Treated }\end{array}$ & $4-30$ & $\begin{array}{r}33.3 \\
3.7\end{array}$ & $\begin{array}{l}4.3 \\
0\end{array}$ & $\begin{array}{l}1.2 \\
0\end{array}$ & $\begin{array}{l}0 \\
0\end{array}$ \\
\hline $\begin{array}{l}\text { Control } \\
\text { Treated }\end{array}$ & $31-90$ & $\begin{array}{r}38.4 \\
4.1\end{array}$ & $\begin{array}{l}2.2 \\
2.2\end{array}$ & $\begin{array}{l}1.5 \\
0\end{array}$ & $\begin{array}{l}0.7 \\
0\end{array}$ \\
\hline $\begin{array}{l}\text { Control } \\
\text { Treated }\end{array}$ & $91-150$ & $\begin{array}{r}39.6 \\
6.1\end{array}$ & $\begin{array}{l}3.0 \\
2.7\end{array}$ & $\begin{array}{l}0.9 \\
0.4\end{array}$ & $\begin{array}{l}0 \\
0\end{array}$ \\
\hline $\begin{array}{l}\text { Control } \\
\text { Treated }\end{array}$ & $151-240$ & $\begin{array}{r}44.3 \\
7.7\end{array}$ & $\begin{array}{l}2.1 \\
1.9\end{array}$ & $\begin{array}{l}1.7 \\
0\end{array}$ & $\begin{array}{l}0 \\
0.6\end{array}$ \\
\hline $\begin{array}{l}\text { Control } \\
\text { Treated }\end{array}$ & $>241$ & $\begin{array}{l}43.2 \\
12.2\end{array}$ & $\begin{array}{l}0.9 \\
1.8\end{array}$ & $\begin{array}{l}0.9 \\
0\end{array}$ & $\begin{array}{l}0 \\
0.3\end{array}$ \\
\hline $\begin{array}{l}\text { Control } \\
\text { Treated }\end{array}$ & Drying off & $\begin{array}{l}41.5 \\
10.4\end{array}$ & $\begin{array}{l}1.1 \\
1.7\end{array}$ & $\begin{array}{l}1.1 \\
0\end{array}$ & $\begin{array}{l}0 \\
0\end{array}$ \\
\hline
\end{tabular}

${ }^{1}$ Data expressed as percentage of quarter samples.

${ }^{2} \mathrm{n}=168$ untreated quarters and 160 antibiotic-treated quarters.

${ }^{3}$ Days before expected calving.

${ }^{4}$ Coagulase-negative Staphylococcus species.

${ }^{5}$ Streptococcus species.

${ }^{6}$ Gram-negative rods.

tained at $3 \mathrm{~d}$ after calving and $7 \%$ of samples obtained 4 to $30 \mathrm{~d}$ postpartum from quarters of antibiotic-treated heifers contained mastitis pathogens. Throughout the remainder of lactation, mastitis pathogens were isolated from an average of $12 \%$ of quarters. Percent of samples with mastitis pathogens was higher $(P<0.001)$ in untreated controls than in antibiotic-treated quarters at every sampling interval during lactation (Figure 2). Coagulase-negative Staphylococcus species, Strep. uberis, and Strep. dysgalactiae were isolated most frequently in both untreated controls and antibiotictreated heifer mammary glands (Table 2).

Actual milk production and mean 305-d milk production were higher $(P<0.05)$ in heifers treated with antibiotics (Figure 3). Prepartum antibiotic-treated heifers produced $531 \mathrm{~kg}$ more milk $(P<0.05)$ than untreated control heifers. In addition, heifers treated with antibiotics before calving had a lower $(P<0.05)$ SCC score than control heifers (Figure 4, 2.63 vs. 2.04).

Prepartum antibiotic treatment to reduce the rate of mastitis in heifers during early lactation was economically beneficial. Actual milk production averaged 5195 $\mathrm{kg}$ for untreated heifers and $5726 \mathrm{~kg}$ for antibiotictreated heifers. Multiplying the increase in actual milk production $(531 \mathrm{~kg})$ in prepartum antibiotic-treated heifers by a milk price of $\$ 0.407 / \mathrm{kg}$ yielded a $\$ 216.24$ per-heifer increase in gross revenue (Table 3). Subtracting the cost of treatment $(\$ 15.60 /$ heifer $)$ from gross 
Table 3. Net revenue increase per heifer from precalving antibiotic treatment.

\begin{tabular}{lrl}
\hline Revenue or cost & & \\
\cline { 2 - 3 } & & \\
Revenues & & 216.24 \\
Increased milk production & & \\
$\quad(531 \mathrm{~kg} /$ heifer@ $\$ 0.407 / \mathrm{kg})$ & & \\
Costs & 0.10 & \\
$\quad$ Teat hygiene (teat disinfectant, & 10.00 & \\
paper towels, and barrier teat dip) & 2.50 & \\
Antibiotic $($ Cephapirin or Cloxacillin) & 3.00 & \\
Labor cost $(0.25$ hr@ $\$ 10.00 / \mathrm{hr})$ & & 200.64 \\
Antibiotic residue test & & \\
Total cost & & \\
Net revenue increase from treatment & & \\
& &
\end{tabular}

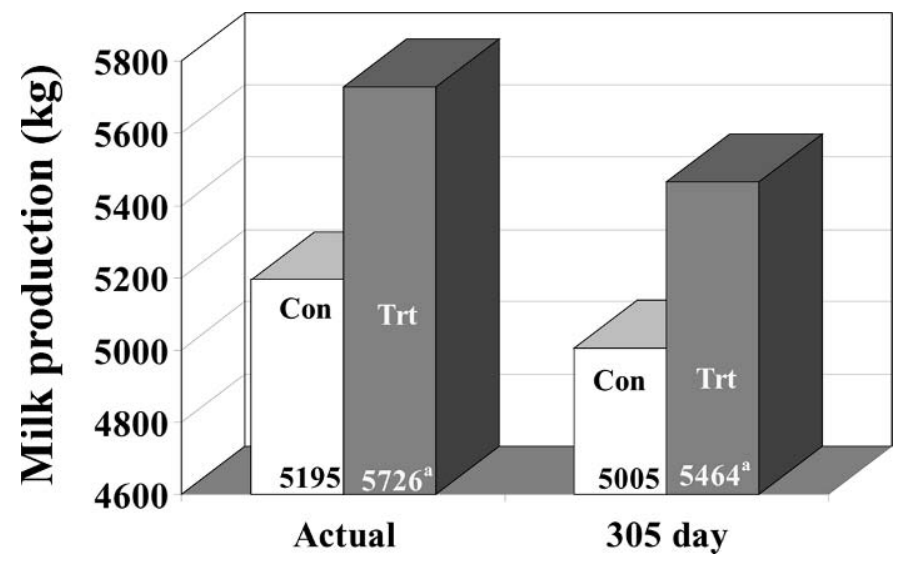

Figure 3. Actual and 305 day milk production in control and prepartum antibiotic-treated heifers. ${ }^{a}$ Significantly different from controls $(P<0.05)$.

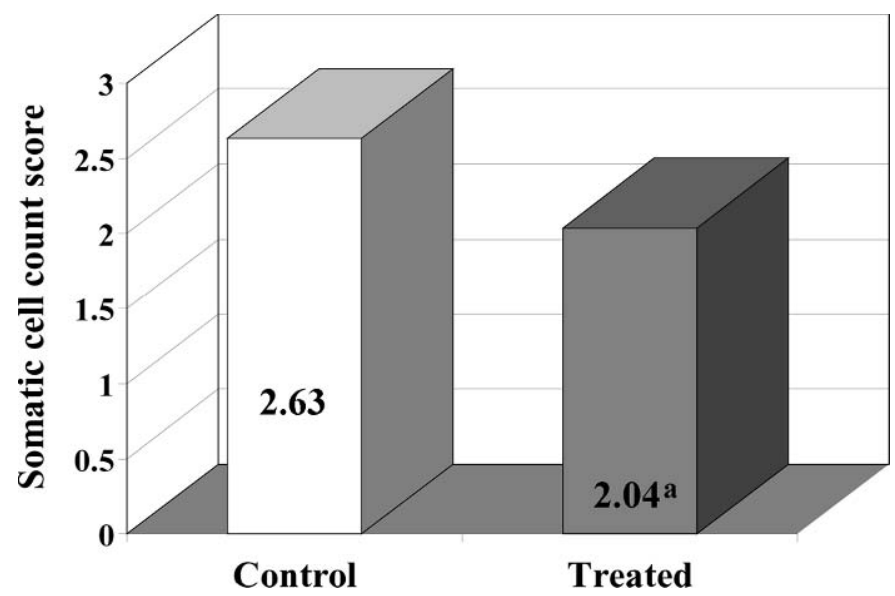

Figure 4. Lactation average somatic cell count score in milk from control and prepartum antibiotic-treated heifers. ${ }^{\text {aSignificantly dif- }}$ ferent from controls $(P<0.05)$.

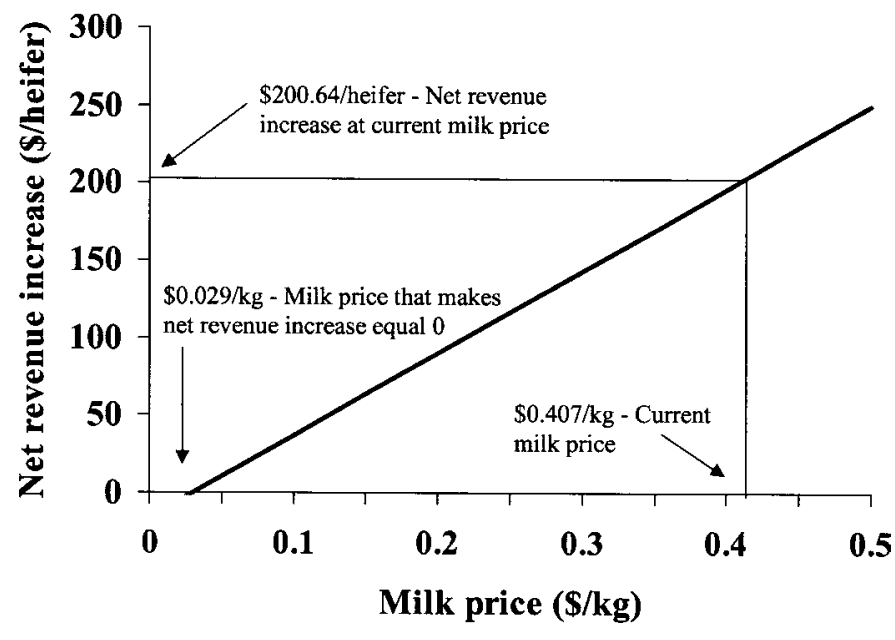

Figure 5. Graphical relationship between the increase in net revenue over an entire lactation and milk price.

revenue, resulted in a net revenue increase of $\$ 200.64$ per heifer. These net revenue figures included the cost of testing for antibiotic residues for all antibiotictreated heifers.

Break-even analysis indicated that treatment of heifers with antibiotics before calving would be profitable as long as the milk price was above $\$ 0.029 / \mathrm{kg}$ (Figure 5). This analysis suggests that the milk price would not likely fall low enough to make treatment of prepartum heifers unprofitable. A similar analysis for the wage rate suggests that treating heifers with antibiotics before calving would be profitable for wage rates below $\$ 812.56 /$ hour (Figure 6). The relationship between net revenue increases and the increase in milk produced

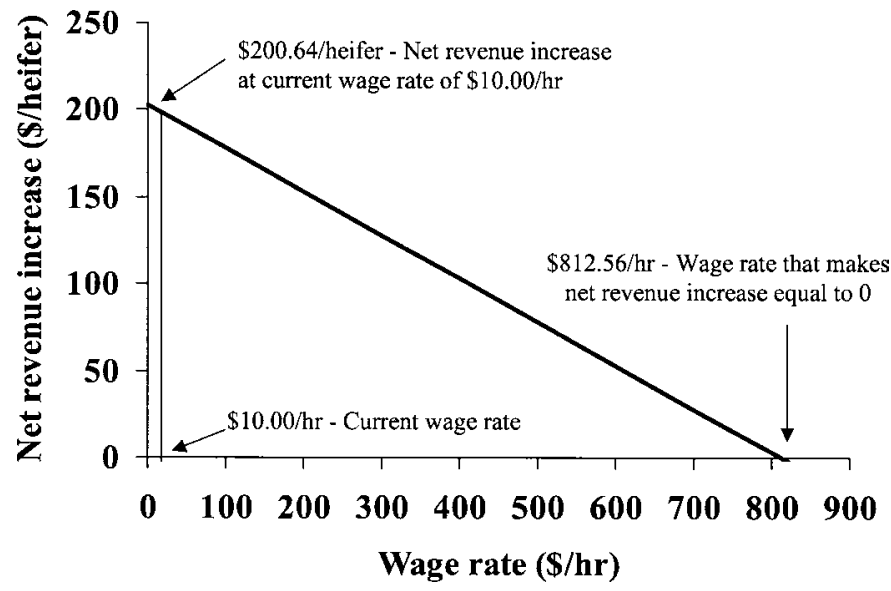

Figure 6. Graphical relationship between the increase in net revenue over an entire lactation and the hourly wage rate of labor. 


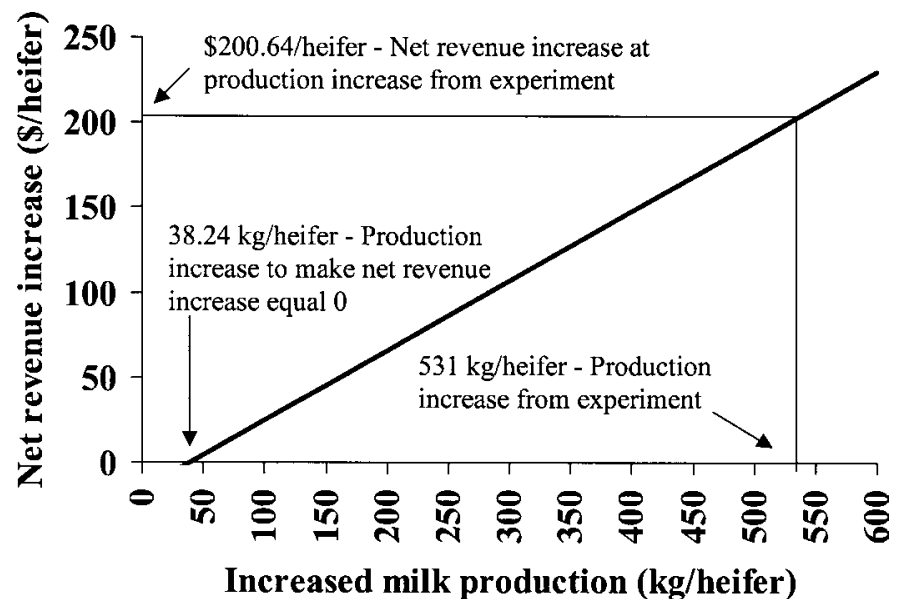

Figure 7. Graphical relationship between net revenue increases over an entire lactation and the increase in $\mathrm{kg}$ of milk produced due to treatment.

due to treatment (Figure 7) suggests that treatment would be profitable as long as the increase in milk production is $>38.2 \mathrm{~kg} / \mathrm{heifer}$.

Intramammary infections in breeding age and pregnant heifers are much higher than previously thought. Many of these infections can persist for long periods of time, are associated with elevated SCC (Trinidad et al., 1990b; Hallberg et al., 1995), and may impair mammary development (Trinidad et al., 1990b) and affect milk production after calving. Prepartum intramammary antibiotic infusion of heifer mammary glands with lactating cow antibiotic formulations used in the present study was an effective procedure for eliminating many infections in heifers during late gestation and for reducing the prevalence of mastitis in heifers during early lactation and throughout lactation.

Trinidad et al. (1990c) demonstrated that intramammary infusion of an antibiotic formulation for nonlactating cows into breeding age and pregnant heifers during different trimesters of pregnancy was effective in reducing the prevalence of mastitis and somatic cell counts at parturition. However, efficacy of prepartum antibiotic therapy at 7 or $14 \mathrm{~d}$ before expected calving in our studies (Oliver et al., 1992, 1997) was considerably higher than that reported by Trinidad et al. (1990c). This finding could be due, in part, to the time when heifers were treated with antibiotics, differences in the pathogens causing IMI, and the time when IMI occur. In support of this hypothesis, Fox et al. (1995) indicated that the prevalence of heifer IMI was highest during the last trimester of pregnancy. Thus, methods of controlling mastitis in heifers would likely be more effective if administered during the last trimester of pregnancy as opposed to early gestation.

\section{CONCLUSIONS}

Prepartum intramammary antibiotic infusion of heifer mammary glands with lactating cow antibiotic formulations is an effective procedure for eliminating many infections in heifers during late gestation and for reducing the prevalence of mastitis in heifers during early lactation and throughout lactation. Prepartum antibiotic-treated heifers produced significantly more milk than control heifers and had significantly lower SCC scores than untreated control heifers. These observations are likely associated with or due to the lower prevalence of mastitis pathogen isolation in prepartum antibiotic-treated heifers throughout lactation. There is little question of the economic benefit associated with prepartum antibiotic treatment of pregnant heifers. Results were quite robust for swings in the price of milk, the wage rate, and even the relative increase in milk production. As it becomes more widely known and understood that heifers have a high prevalence of intramammary infections near calving, it is likely that prepartum antibiotic treatment will become accepted as a general cost-effective procedure to reduce mastitis in heifers.

\section{ACKNOWLEDGMENTS}

This work was supported by the Tennessee Agricultural Experiment Station and The University of Tennessee College of Veterinary Medicine Center of Excellence Research Program in Livestock Diseases and Human Health. Author expresses their appreciation to personnel in the Lactation/Mastitis/Food Safety Research Program at The University of Tennessee and to personnel at DES and MTES dairies for their excellent technical assistance.

\section{REFERENCES}

Boehlje, M. D., and V. R. Eidman. 1984. Farm Management. John Wiley \& Sons, New York.

Fox, L. K., S. T. Chester, J. W. Hallberg, S. C. Nickerson, J. W. Pankey, and L. D. Weaver. 1995. Survey of intramammary infections in dairy heifers at breeding age and first parturition. J. Dairy Sci. 78:1619-1628.

Hallberg, J. W., K. J. Dame, S. T. Chester, C. C. Miller, L. K. Fox, J. W. Pankey, S. C. Nickerson, and L. J. Weaver. 1995. The visual appearance and somatic cell count of mammary secretions collected from primigravid heifers during gestation and early postpartum. J. Dairy Sci. 78:1629-1636.

Matthews, K. R., R. J. Harmon, and B. E. Langlois. 1992. Prevalence of Staphylococcus species during the periparturient period in primiparous and multiparous cows. J. Dairy Sci. 75:1835-1839.

Nickerson, S. C., W. E. Owen, and R. L. Boddie. 1995. Mastitis in dairy heifers: initial studies on prevalence and control. J. Dairy Sci. 78:1607-1618.

Oliver, S. P., and B. A. Mitchell. 1983. Intramammary infections in primigravid heifers near parturition. J. Dairy Sci. 66:1180-1183. 
Oliver, S. P. 1987. Intramammary infections in heifers at parturition and during early lactation in a herd with a high prevalence of environmental mastitis. Tennessee Farm Home Sci. 143:18-22.

Oliver, S. P., and L. M. Sordillo. 1988. Udder health in periparturient period. J. Dairy Sci. 71:2584-2606.

Oliver, S. P. 1988. Frequency of isolation of environmental mastitis causing pathogens and incidence of new intramammary infection during the nonlactating period. Am. J. Vet. Res. 48:1789-1793.

Oliver, S. P., M. J. Lewis, B. E. Gillespie, and H. H. Dowlen. 1992. Influence of prepartum antibiotic therapy on intramammary infections in primigravid heifers during early lactation. J. Dairy Sci. 75:406-414.

Oliver, S. P., M. J. Lewis, B. E. Gillespie, and H. H. Dowlen. 1997. Antibiotic residues and prevalence of mastitis pathogen isolation in heifers during early lactation following prepartum antibiotic therapy. J. Vet. Med. B 44:213-220.
Pankey, J. W., P. A. Dreschsler, and E. E. Wildman. 1991. Mastitis prevalence in primigravid heifers at parturition. J. Dairy Sci. $74: 1550-1552$.

Smith, K. L., J. S. Hogan, D. A. Todhunter, W. P. Weiss, and P. S. Schoenberger. 1994. Intramammary infection and clinical mastitis in heifers at calving and dynamics over a 14 year period in a dairy herd. J. Dairy Sci. 77(Suppl. 1):197. (Abstr).

Trinidad, P., S. C. Nickerson, and T. K. Alley. 1990a. Prevalence of intramammary infection and teat canal colonization in unbred and primigravid dairy heifers. J. Dairy Sci. 73:107-114.

Trinidad, P., S. C. Nickerson, and R. W. Adkinson. 1990b. Histopathology of staphylococcal mastitis in unbred heifers. J. Dairy Sci. 73:639-647.

Trinidad, P., S. C. Nickerson, T. K. Alley, and R. W. Adkinson. 1990c. Efficacy of intramammary treatment in unbred and primigravid dairy heifers. J. Am. Vet. Med. Assoc. 197:465-470. 